\title{
Impact of Misleading Advertisements: Issues and Remedies
}

\author{
C. Jeeva
}

\begin{abstract}
Advertising is one of the public media options used to reach out to an audience, create and sustain their interest through words and illustrations to encourage them to buy a particular product or a service.

The communication can be made either through mass media or through new media. The Mass media includes newspapers, television, magazines, commercials, Radio advertising and the new media includes blogs, websites or text messages. The rationale behind advertising is to update the consumer regarding a particular product and its availability in the market. The prime objective of advertising is toward generating demand used for new products by attracting the interests of public towards it. Further; it is intended to enhance the awareness among the customers. Ambiguous and deliberate attempt to mislead can have serious economic consequences, especially when exposed to large target groups or when it occurs for long duration. Such advertisements will adversely affect the sales of the product and its brand image and in the end the producer and distributors as well. Sometimes competitors honest promotional efforts of the same product will also be affected since the consumer will presume all advertisements are bogus. Such a practice is unethical. From consumers end he will pay higher price for the product based on the tall claim made and the product does not match the claim. One does not fundamentally object to any exaggeration in the manner the products is advertised but when it extends to falsehood exaggerating the facts to hood wink the customer then it becomes unacceptable. This article highlights such issues and looks at the concepts of misleading advertisements and their impact on Indian consumers. The article also aims to provide possible remedies to end such practices and ensure healthy and fair advertisement strategies.
\end{abstract}

"Advertising may be described as the science of arresting human intelligence long enough to get money from it.

-Stephen Leacock

\section{INTRODUCTION}

$\mathrm{M}$ ISLEADING advertisements affect consumer's choices regarding what they buy. Such advertisements create an expectation about the quality of the product that is not true. Advertisements of this kind are not only dishonest but will create a wrong impression about the product and consumer preference will be distorted.

C. Jeeva, M.A, M.Phil, NET., Assistant Professor, Department of Economics, Providence College for Women, Coonoor. E-mail: jeeva2018@gmail.com,jimaarn1983@yahoo.com DOI:10.9756/BIJIEMS.7616
Advertisements that deliberately highlights virtues of the products or services that do not exist violates the rights of the consumers like the right to information and can be sued under unfair trade practices. Such advertisements can have negative economic impact when addressed to large public or when they are exposed to the advertisements for long period of time. It can affect both the advertised product as well as competitor's identical product since the public reaction would be to reject both even though the honest competitor is engaged in honest business promotion.

The act of knowingly advertising a product or service that does not exist or does not function as in recent times large number of condemnable advertisements appear more so in local language media promising to cure venereal diseases, stimulants for impotency peculiar to both the sexes.

They play on the psychology of these people who are shy to go to genuine doctors. Due to ignorance and carried away by the advertisements they not only get trapped but also spend large sum of money in vain. They also are emotionally and physically affected and are too ashamed to talk about it and go to genuine doctors. People and media involved in promoting such activities can be a real menace to the society if they go unpunished, unobserved and therefore deserve censure and heavy penalty if not imprisonment. The death of the patient and quack practicing native medicine are lessons to learn from.

With a view to control the advertisement of drugs in certain cases and to prohibit the advertisement for remedies alleged to process magic qualities and the provide for matters connected there with, the drugs and magic Remedies (Objectionable Advertisement) Act was enacted in 1954 (here in after referred to as DMR Act).

The main objective of DMR Act is to control the advertisement of drugs in certain cases and to prohibit publishing of advertisements that promises magical cures. This cure includes not only some drugs or herbs but also external curatives like chants, specially made talismans and any form of treatment that borders magic and magic potions. Examples and instances of misleading Advertisement Include:

Assurances to heal fatal diseases like cancer, Aids for which allopath has been accepted as possible treatment but not sure. Even though Drugs and Magic Remedies Act stated that no medical practitioner should make a claim in the schedule under section 3 .

A practitioner advertising his clinic asserted that he had a sure cure for epilepsy. Following a complaint from one of his patients that he was prescribing high doses of a lethal 
medicine, on the basis of the findings of a committee Indian Medical Association (IMA) declared him as a fraud.

The Advertising Standard council of India (ASCI) also held that advertisement violated the drugs and Magic Remedies (Objectionable Advertisements) Act. Even then it was sad that the quack went ahead with his advertisements and the drug control departments failed to stop him and he continued his trade risking the lives of thousands of his patients. One has to also recall the news item (Nov 12) in a TV channel who promises to cure cancer with herbs and bring the dead alive.

In another case a young girl, born of short height was attracted by an advertisement that promised to convert a dwarf in to a stature measuring $10 \mathrm{~cm}$ in 6 months through surgery. The so called correction surgery left her confined to bed.

India is the land of spiritualist of babas and sadhus and the gullible uneducated and educated alike fall into their trap. There is no specific and stringent law to punish such native doctors who make false promises cheat them and get away with it. Due to unawareness, innocent people get into the trap of false belief and not only end up losing large sum of money but also suffer from immense harm and bodily injury people involved in promoting such acclivities can be a real menace to the socially if kept unobserved and three fore reserve serve censure and penalty.

With a view to control the advertisement of drugs in certain cases and to prohibit the advertisement for remedies alleged to process magic qualities and the provide for matters connected three with, the drugs and magic Remedies

\section{False Claims and Misleading Advertising}

As provided under Section 36A (1) of the MRTP Act, the following statements, whether made orally or in writing or by visible representation, would amount to an unfair trade practice:

- Falsely representing that the goods are of particular standard, quality, quantity, grade, composition, style or model.

- Falsely representing that the services are of particular standard, quality or grade.

- Falsely representing any re-built, secondhand, renovated, reconditioned or old goods as new goods.

- Representing that the goods or services have sponsorship, approval, performance characteristics, accessories, uses or benefits, which such goods or services do not have.

- Representing that the seller or supplier has a sponsorship, approval or affiliation which he does not have.

- Making a false or misleading representation about the need or usefulness of any good or service.

- Giving any warranty or guarantee about the performance, efficacy or length of life of a Product that is not based on an adequate test.

- Making to the public a misleading or false

1. Warranty or guarantee for a product or service.
2. Promise to replace, maintain or repair an article or to repeat or continue a service until it has achieved a specified result.

- Misleading the public about the price of any product or the charge of any service.

- Giving false or misleading facts disparaging the goods, services or trade of any person.

It has been clarified that for the purpose of determining whether any statement amounts to a false representation or a misleading advertisement, each of the following types of statements shall be deemed to be a statement made to the public.

\section{Regulation of Misleading Advertising under MRTP Act}

Under the MRTP Act, false and deceptive advertisements are sought to be restricted through a 'cease and desist' order, or any other similar direction, issued by the MRTP Commission. Before giving effect to such an order, the Commission is required to conduct an inquiry into the alleged irregular advertisement in keeping with rules under which the MRTP Commission is empowered to initiate such an inquiry on any one of the four bases (Section 36B):

- A complaint received from any consumer or any registered consumers' association or any trade association.

- A reference received from the central government or any state government.

- An application received from the Director- General of Investigation and Registration.

- On its own knowledge or information.

\section{Legal Protection of Consumers}

The growth interdependence of the world economy and international character of many business practices have contributed to the development of universal emphasis on consumer right projection and promotion, consumers, clients, and customers all over the world, are demanding value for money in the form of quality goods and better services.

Recent developments in technology and science have positively impacted on the quality, cost and safety in uses of the goods and services. In reality unfortunately the consumers are still hood winked and fleeced by unscrupulous people who take advantage of the ignorance of the victims. This takes many forms such as adulteration if it food and consumer goods, spurious if they are drugs, misleading conditions and terms of repayment if it is hire purchase or EMI, deficient after sales service, advertisements with exaggerated promises, and black marketing if the product is in short supply.

"Consumer is sovereign "and "Consumer is the kings" are mere words to flatter and entice and is nothing more than myths in the present scenario particularly in the developing stages. But at the same time now there is an awareness that right $\mathrm{s}$ of the consumer is an integral part of socio economic development of a nation. The government is also empowering the people more so those affected consumers to seek remedy from various consumer grievance redressal forums that has eminent honest men and women from public life who protect the interests of the consumers. 
In this context, the government, however, has a primary responsibility frame the appropriate policy measures, legal structure and administrative framework.

In this age of fierce competition wars are often fought by the competing industrial giants through of means of advertisements. Advertisement has become such an important and potent weapon to promote particular products that companies think of innovative and attractive ways to woo the consumers. For this purpose services of specialized advertising agencies are hired by the companies.

Consumer Protection: Even political parties use these agencies to devise attractive ways to entice the voters.

Although most false advertising claims brought against advertisers are by competitors, consumers can also file such claims. No hard-and-fast rules exist for all consumer-initiated cases; courts deal with claims brought by consumers on more of a case-by-case basis than they do with claims brought by competitors. The issues surrounding consumer rights were discussed during the drafting of the 1988 Trademark Law Revision Act, but were not resolved.

In cases where consumers have sued, they have most often been held to the same standards as competitors: they need to show that they have a reasonable interest in order to be protected. This standard was demonstrated by the Class Action lawsuit of Maguire v. Sandy Mac, 138F.R.D. 444 (D.N.J. 1991). In that case, the class included both resellers, who had purchased a ham product from the defendant, and consumers, who had ultimately bought the ham products. The lawsuit claimed that the defendant sold ham products falsely represented as meeting U.S. DEPARTMENT OF AGRICULTURE standards. The court ruled for the plaintiffs, saying that "the plaintiff and the proposed class, the consumers, have a reasonable interest in being protected from criminal misrepresentations."

Another way consumers are protected is by state laws on deceptive trade practices. Some state laws define these practices as showing goods or services with the intention of not actually selling them as advertised. In Affrunti v. Village Ford Sales, 232 Ill. App. 3d 704, 597 N.E.2d 1242 (3rd. Dist. Ct. App. 1992), a consumer filed a lawsuit against an automobile dealership that sold him a car for more money than it was actually advertised for. Ronald Affrunti went to Village Ford Sales, a used-car lot, and looked at a blue 1986 Celebrity with 29,000 miles on the odometer. The car did not have a sticker price, so he asked the salesman, Fred Galaraza, for a price. Galaraza answered that he would have to check in his office. After showing Affrunti several other used cars, and without going to his office, Galaraza quoted a price of $\$ 8,600$ for the Celebrity. Affrunti and Galaraza settled on a final price of $\$ 8,524$, which included a trade-in and a discount for a frontend alignment. Upon returning home, Affrunti came across an advertisement by Village Ford Sales for a 1986 blue Celebrity with 29,999 miles on the odometer for \$6,995. Affrunti called the dealership. Galaraza checked and said, "By God, it's the same!" Affrunti asked to redo the deal based on the advertised price. Galaraza put him on hold. When Galaraza came back on the line, he said the car in the ad had been sent to auction, and they could not redo the deal because it was not the same car.

At trial, the sales manager testified that prices listed in advertisements are not necessarily the listed cars' actual prices; dealers can sell the cars for higher prices. After hearing the evidence, the judge ruled that the dealer had an obligation to inform the plaintiff of the advertised price of the car, and awarded Affront the difference between the purchase price and the advertised price, which amounted to $\$ 1,529$. On appeal, the Illinois Appellate Court ruled that "the defendant's failure to disclose the advertised sale price constituted deceptive conduct under the Consumer Fraud Act." The appellate court also added attorneys' fees to Affront's award, bringing the total up to $\$ 1,937.50$.

\section{CONCLUSION}

An ad that is misleading continues to prove difficult and controversial. Naturally, advertisers and consumer advocates rarely agree on whether a particular ad is misleading. A producer for identifying misleading advertising is presented, based solely on measured consumer beliefs. An advertisement is misleading if an exposed group holds more false belief than a comparison group. When ten allegedly misleading advertisement were tested, two were identified as inclemently misleading and four others were shown to be exploitive misleading. Thus a misleading advertisement has adverse effect on consumer welfare and must be regulated by the legal provisions and institutional framework that regulate misleading advertisements in our country. There by Consumer should be rational in thinking to see beyond the packaging of words and illustrations while viewing and go for a purchase of goods or services. Maggie is a classic example where even the presence and words of eminent movie stars could not hide the deficiencies of the product that they had to review and correct the content.

\section{REFERENCES}

[1] CERS press Release, November 21, 2003.

[2] Drugs \& Magic Remedies (Objectionable Advertisement) Act, 1954.

[3] D.P. Verma, "Regulating Misleading Advertisements: Legal Provisions and Institutional Framework” Vikalpa, Vol. 26, No. 2, Pp. 51-58, 2001.

[4] www.legalprojectionofconsumer.com

[5] www.labourguide.co.za/consumer-protection/1170-the-consumerprotection-act-your-guide-to-consumer-rights-a-how-to-protect-them.

[6] Priyanka Rastog, Magic Drugs and Misleading Advertisement, 2012. 